\title{
Dampak Layanan Transportasi Online Terhadap Kesejahteraan Perekonomian Masyarakat Kota Mojokerto Melalui Kesempatan Kerja
}

\author{
Khasbulloh Huda ${ }^{1 *}$, Zenita Afifah Fitriyani ${ }^{2}$, Rachmad Sholeh ${ }^{3}$, Mohammad \\ Johan Effendi ${ }^{4}$ \\ 1,2,3,4 Universitas Mayjend Sungkono Mojokerto, Indonesia \\ *email: hudakhasbulloh2@gmail.com
}

\begin{abstract}
This study aims to determine the impact of online transportation services on the economic welfare of the people of Mojokerto City through job opportunities. This research was conducted with a quantitative approach using a survey method and using random sampling data collection method. While the measurement uses a Likert scale. The data collection method used a questionnaire. The data analysis method in this study uses PLS (Partial Least Square) with the smartPLS 3.0 program. The results showed that the variable of Online transportation services have a direct influence on job opportunities for the people of the City of Mojokerto with a T statistic of 9.007 ( $\mathrm{P}$ value $=0.000)$. Online transportation services have a direct influence on the economic welfare of the people of Mojokerto city with a $\mathrm{T}$ statistic of $10,746(\mathrm{P}$ value $=0.000)$. Job opportunities have an influence on the economic welfare of the people of Mojokerto City with a $\mathrm{T}$ statistic of 11.471 (P value = 0.000). Online transportation services have an influence on the economic welfare of the people of Mojokerto city through job opportunities with a T statistic of 7.193 (P value = 0.000).
\end{abstract}

Keywords: online transportation services, community economic welfare, job opportunities.

\begin{abstract}
Abstrak: Penelitian ini bertujuan untuk mengetahui dampak layanan transportasi online terhadap kesejahteraan perekonomian masyarakat Kota Mojokerto melalui kesempatan kerja. Penelitian ini dilakukan dengan pendekatan kuantitatif yang menggunakan metode survey. serta menggunakan metode pengambilan data random sampling. Sedangkan pengukuran menggunakan skala likert. Adapun metode pengumpulan data menggunakan kuesioner. Metode analisis data dalam penelitian ini menggunakan PLS (Partial Least Square) dengam program smartPLS 3.0. Hasil penelitian menunjukkan bahwa variabel layanan transportasi online memiliki pengaruh langsung terhadap kesempatan kerja pada masyarakat Kota Mojokerto dengan perolehan $\mathrm{T}$ stastistik sebesar 9,007 ( $\mathrm{P}$ value $=0,000)$. Layanan transportasi online memiliki pengaruh langsung terhadap kesejahteraan perekonomian masyarakat Kota Mojokerto dengan $\mathrm{T}$ stastistik sebesar 10,746 ( $\mathrm{P}$ value $=$ 0,000). Kesempatan kerja memiliki pengaruh terhadap kesejahteraan perekonomian masyarakat kota Mojokerto dengan $\mathrm{T}$ stastistik sebesar 11,471 ( $\mathrm{P}$ value $=0,000$ ). Layanan transportasi online memiliki pengaruh terhadap kesejahteraan perekonomian masyarakat Kota Mojokerto melalui kesempatan kerja dengan $\mathrm{T}$ stastistik sebesar 7,193 (P value = $0,000)$.
\end{abstract}

Kata Kunci: Layanan Transportasi Online, Kesejahteraan Perekonomian Masyarakat, Kesempatan Kerja

\section{PENDAHULUAN}

Dalam mewujudkan masyarakat yang sejahtera dan makmur, maka sebuah negara perlu meningkatkan pertumbuhan ekonomi, artinya jika terjadi penambahan kegiatan perekonomian yang menyebabkan barang dan jasa bertambah, maka kesejahteraan masyarakat akan meningkat (Fahrizal et al., 2021). Kesejahteraan dapat dilihat dari banyak aspek misalnya dari kondisi lingkungan, sosial, dan perekonomian 
masyarakat. Sehingga dalam mencapai kesejahteraan masyarakat maka perlu melaksanakan perubahan kehidupan yang lebih baik (Indrayani dan Setiawina, 2018). Salah satu hal yang mempengaruhi kesejahteraan masyarakat adalah tingkat pengangguran, karena pengangguran berdampak pada menurunnya tingkat perekonomian negara, sehingga jumlah kemiskinan juga meningkat (Alfadri, 2019a).

Fenomena wabah pandemi Covid-19 di Indonesia memiliki dampak yang besar bagi segala aspek ekonomi dan kehidupan masyarakat, termasuk yang terjadi pada masyarakat Kota Mojokerto, karena kejadian tersebut tidak hanya menyebabkan banyak masyarakat meninggal dan sakit akibat virus Covid-19, namun pertumbuhan ekonomi daerah Kota Mojokerto menurun drastis sebesar $0.05 \%$ dibandingkan saat sebelum wabah terjadi. Selain itu tingkat pengangguran di Kota Mojokerto juga meningkat akibat banyak masyarakat yang diPHK dan sebagian dirumahkan dengan batas waktu yang tidak ditentukan dalam mengurangi jumlah tenaga kerja (Astuti, 2021). Adapun Tingkat pengangguran yang ada di Kota Mojokerto tahun 2018, 2019 dan 2020 dapat dilihat pada tabel 1 berikut ini;,

Tabel 1. Tingkat Pengangguran tahun 2018, 2019 dan 2020

\begin{tabular}{lccc}
\hline \multicolumn{1}{c}{ Jenis Kegiatan } & $\mathbf{2 0 1 8}$ & $\mathbf{2 0 1 9}$ & $\mathbf{2 0 2 0}$ \\
\hline Bekerja & 66.833 & 63.091 & 65.208 \\
\hline Pengangguran & 1.679 & 1.715 & 4.712 \\
\hline
\end{tabular}

Sumber : (BPS Kota Mojokerto, 2020)

Dari tabel di atas terlihat bahwa tingkat pengangguran pada tahun 2018 sebesar 1.679 orang, tahun 2019 sebesar 1.715 orang, dan tahun 2020 angka pengangguran melonjak sebesar 4.712 orang artinya terjadinya wabah Covid-19 sangat berdampak pada tingginya angka pengangguran. Menurut Hariyanto, Kepala Dinas Usaha Mikro dan Tenaga Kerja Kota Mojokerto menyatakan jumlah pengangguran masih dianggap tinggi, karena berkisar ribuan warga yang masih tidak memiliki pekerjaan (Radar Mojokerto, 2019). Salah satu hal yang dapat membantu perbaikan pertumbuhan perekonomian masyarakat adalah dengan membuka lapangan kerja dan menyerap angkatan kerja agar dapat mengurangi pengangguran, karena tujuan pembangunan pada dasarnya mencapai kesejahteraan masyarakat untuk mendukung pertumbuhan ekonomi negara (Pratiwi dan Indrajaya, 2019).

Menurut Sari dan Yuedrika (2019), menyatakan bahwa pada dasarnya kesejahteraan masyarakat akan terpenuhi apabila masyarakat dapat memenuhi kebutuhan keluarganya seperti sandang, pangan, papan, sosial dan agama, memiliki keseimbangan antara penghasilan, jumlah keluarga, dan terpenuhinya kesejahteraan kesehatan anggota keluarga. Fakhriyah (2020), menambahkan bahwa perluasan lapangan pekerjaan memiliki hubungan dengan pendapatan penghasilan masyarakat, 
oleh karena itu pendapatan penghasilan dapat membantu kesejahteraan perekonomian masyarakat. Indikator kesejahteraan masyarakat dapat diukur dari pendidikan, ketenagakerjaan, pola konsumsi, kemiskinan, dan sosial (BPS Kota Mojokerto, 2020)

Penyerapan kerja juga menjadi pendukung dalam menciptakan pembangunan ekonomi secara merata, karena tercapainya pertumbuhan ekonomi dan kesejahteraan masyarakat dapat terwujud jika memiliki sumberdaya yang efektif. Oleh karena itu, kesejahteraan perekonomian masyarakat dan kesempatan kerja memiliki keterkaitan yang menggambarkan kesempatan kerja adalah jumlah penduduk yang memiliki kesempatan dalam bekerja serta kesejahteraan perekonomian masyarakat digambarkan dalam peran masyarakat untuk mencapai tujuan pembangunan (Awandari dan Indrajaya, 2016). Tingkat kesempatan kerja dapat dilihat dari kebutuhan tenaga kerja, sedangkan kebutuhan tenaga kerja dapat dilihat dari jumlah angkatan kerja, dimana kesempatan kerja dapat dikatakan sebagai hubungan antara angkatan kerja dengan kemampuan penyerapan tenaga kerja untuk mendapatkan kesempatan dalam memperoleh pekerjaan, sehingga jika angkatan kerja meningkat maka perlu perluasan lapangan pekerjaan (Rostini et al., 2020). Dalam mewujudkan perluasan kesempatan kerja di Kota Mojokerto, pemerintah mendukung dengan memberikan wadah melalui menyelenggarakan pameran bursa kerja, hal itu dilakukan berdasaarkan besarnya jumlah penduduk yang meningkat, sehingga semakin meningkat pula jumlah angkatan kerja di Kota Mojokerto. Permasalahan tentang kesempatan kerja perlu segera mendapatkan solusi agar menurunkan jumlah pengangguran terbuka yang berpengaruh pada peningkatan kesejahteraan perekonomian masyarakat (PPID Kota Mojokerto, 2017). Adapun jumlah angkatan kerja Kota Mojokerto tahun 2020 dapat dilihat pada tabel 2 dibawah ini;

Tabel 2. Jumlah Angkatan Kerja Kota Mojokerto Tahun 2020

\begin{tabular}{lrrr}
\hline Pendidikan Tertinggi yang & \multicolumn{3}{c}{ Angkatan Kerja } \\
\cline { 2 - 4 } Ditamatkan & \multicolumn{1}{c}{ Bekerja } & Pengangguran & Total Angkatan Kerja \\
\hline Tidak/Belum tamat SD & 8.782 & 530 & 9.312 \\
\hline SD & & & 9.914 \\
\hline SMP & 9.520 & 394 & 34.443 \\
\hline SMA/SMK & 31.477 & 2.966 & 16.251 \\
\hline D1, D2, D3, S1 & 15.429 & 822 & $\mathbf{6 9 . 9 2 0}$ \\
\hline \multicolumn{1}{c}{ Total } & $\mathbf{6 5 . 2 0 8}$ & $\mathbf{4 . 7 1 2}$ &
\end{tabular}

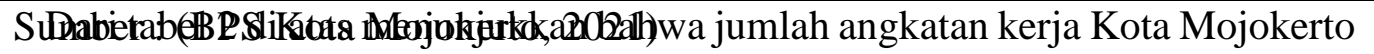
tahun 2020 baik dari penduduk yang masih bekerja maupun pengangguran sebesar 69.920 orang. Dadang Hardiawan, Kepala BPS Jawa Timur menyatakan bahwa tingkat partisipasi angkatan kerja sampai bulan Agustus 2020 meningkat sebesar 0,72 persen. Kenaikan angkatan kerja tersebut memberikan indikasi adanya kenaikan potensi ekonomi dari sisi pasokan tenaga kerja (SuaraSurabaya.Net, 2021). 
Menurut Chandra et al. (2020), menyatakan bahwa kesempatan kerja adalah keadaan di mana semua orang yang ingin bekerja pada upah tertentu akan mendapatkan pekerjaan. Kesempatan kerja berkaitan erat dengan tingkat pengangguran, karena semakin tinggi kesempataan kerja maka semakin menurunkan tingkat pengangguran. Gunawan dan Arka (2021), menambahkan bahwa kesempatan kerja merupakan peluang yang harus diperjuangkan oleh para pencari kerja untuk mendapatkan pekerjaan dan kesejahteraan perekonomian dalam keluarga. BPS Kota Mojokerto (2021), menunjukkan di dalam laporan kinerja bahwa kesempatan kerja memiliki keterkaitan yang erat terhadap angkatan kerja, karena semakin tinggi kesempatan kerja maka akan semakin tinggi pula angkatan kerja, sehingga indikator kesempatan kerja dapat diukur dari tingkat bekerja, lama bekerja, jenis pekerjaan, tingkat pengangguran, dan jumlah angkatan kerja.

Beberapa tahun belakangan muncul beberapa pilihan kepada masyarakat agar dapat bekerja dengan menggunakan bantuan teknologi smartphone / gadget yang ada, yaitu menggunakan aplikasi transportasi online seperti Gojek, Uber, Grab dan sebagainya (Alfadri, 2019). Adanya terobosan transportasi online memiliki banyak manfaat bagi pengguna misalnya penggunaan GPS yang dapat diakses dari transportasi online dapat membantu mencari jalan tercepat dan menghindari kemacetan, layanan ini juga menujukkan besarnya tarif sehingga pengguna dapat mengetahui berapa tarif yang harus dibayar pada tujuan yang dikehendaki. Sedangkan bagi masyarakat, layanan transportasi online memberikan dampak yang baik karena menjadi peluang untuk mendapatkan kesempatan kerja (Sari dan Yuedrika, 2019).

Layanan aplikasi online yang sering digunakan di Mojokerto adalah Gojek, Grab dan Max On Jek. Gojek dan Grab sudah dikenal oleh pengguna karena selama ini layanan tersebut sudah digunakan pada kota-kota besar, sedangkan Max On Jek adalah aplikasi ojek online yang baru dan didirikan oleh warga lokal Mojokerto dengan tujuan kehadiran Max On Jek dapat menyediakan lapangan pekerjaan bagi masyarakat Mojokerto (TransonlineWatch.com, 2021). Permasalahan lain yang terjadi mengenai transportasi Kota Mojokerto adalah fasilitas angkutan umum yang di dominasi oleh bus dan mikrolet masih terasa kurang aman, nyaman dan efisien, sehingga penggunanya adalah masyarakat kalangan menengah ke bawah. Sedangkan kalangan menengah ke atas masih tidak mau karena faktor kenyamanan masih dirasa kurang. Dalam menjawab kebutuhan pengguna tersebut, maka muncul beberapa perusahaan layanan transportasi online, sehingga memberikan peluang bagi masyarakat yang ingin memiliki pekerjaan (Aziah dan Adawia, 2018). Keuntungan masyarakat apabila bergabung dengan layanan transportasi seperti Gojek dan Grab yaitu akan mendapatkan pelatihan mulai dari penggunaan telepon hingga keamanan mengemudi, selain itu pengemudi mendapatkan 
$80 \%$ keuntungan, sisanya $20 \%$ dibayarkan keperusahaan termasuk bonus saat pengemudi mencapai target (Mahargiono dan Cahyono, 2017).

Menurut Fakhriyah (2020), menjelaskan transportasi online merupakan perpindahan manusia atau barang dengan menggunakan kendaraan yang memanfaatkan teknologi berbasis internet melalui aplikasi pada smartphone pada kegiatan transaksinya mulai dari aktivitas pemesanan, pembayaran, dan penilaian pada aplikasi tersebut. Bustami dan Laksamana (2019), menambahkan adanya layanan transportasi online dapat memberikan manfaat pada perluasan kesempatan kerja, peningkatan angkatan kerja, dan kesejahteraan pengemudi transportasi online. Selain itu, transportasi online telah menjadi alternatif transportasi bagi masyarakat dengan alasan praktis, kepercayaan, transparansi, fitur, dan diskon. Menurut (Herdiansyah et al., 2018), menyatakan bahwa layanan transportasi online dapat diukur dengan beberapa indikator antara lain kecepatan, keramahan, fisik/keberwujudan (kendaraan), fisik/keberwujudan (pengemudi), dan keamanan (dalam berkendaraan).

Hasil temuan yang diperoleh dari beberapa peneliti terdahulu dapat digunakan sebagai acuan dalam penelitian, hasil penelitian tersebut dapat dilihat pada tabel 3 dibawah ini;

Tabel 3. Penelitian Terdahulu

\begin{tabular}{|c|c|c|c|}
\hline No & Judul & Metode & Temuan \\
\hline 1 & $\begin{array}{lr}\text { Pengaruh } & \text { Adanya } \\
\text { Transportasi } & \text { Online } \\
\text { Terhadap } & \text { Kesejahteraan } \\
\text { Masyarakat Melalui Variabel } \\
\text { Pengangguran di Kota Medan } \\
\text { (Alfadri, 2019) }\end{array}$ & $\begin{array}{l}\text { Metode SEM } \\
\text { dengan bantuan } \\
\text { Program Smart } \\
\text { PLS }\end{array}$ & $\begin{array}{l}\text { - } \text { Transportasi online berpengaruh } \\
\text { positif signifikan terhadap tingkat } \\
\text { pengangguran secara langsung. } \\
\text { - } \text { Transportasi online berpengaruh } \\
\text { positif signifikan terhadap } \\
\text { kesejahteraan masyarakat secara } \\
\text { langsung. }\end{array}$ \\
\hline 2 & $\begin{array}{lr}\text { Pengaruh } & \text { Layanan } \\
\text { Transportasi } & \text { Online } \\
\text { (GOJEK) } & \text { Terhadap } \\
\text { Perluasan Lapangan Kerja } \\
\text { Bagi Masyarakat Di Kota } \\
\text { Cimahi (Fakhriyah, 2020) }\end{array}$ & $\begin{array}{l}\text { Metode } \\
\text { Independent T- } \\
\text { Test }\end{array}$ & $\begin{array}{l}\text { - Layanan transportasi Online } \\
\text { berpengaruh positif signifikan } \\
\text { terhadap perluasan lapangan } \\
\text { kerja dengan peningkatan } \\
\text { pendapatan secara langsung. }\end{array}$ \\
\hline 3 & $\begin{array}{lr}\text { Analisis } & \text { Pengaruh } \\
\text { Transportasi } & \text { Online } \\
\text { Terhadap Kesempatan Kerja } \\
\text { dan Kesejahteraan di Kota } \\
\text { Medan (Sari dan Yuedrika, } \\
\text { 2019) }\end{array}$ & $\begin{array}{l}\text { Metode Regresi } \\
\text { Linear } \\
\text { Sederhana dan } \\
\text { Analisa Jalur }\end{array}$ & 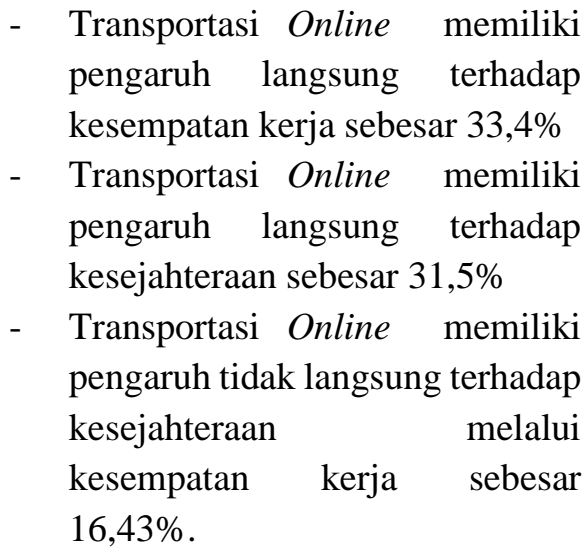 \\
\hline
\end{tabular}

Berdasarkan pemaparan latar belakang tersebut, maka tujuan penelitian ini 
adalah untuk mengetahui dampak layanan transportasi online terhadap kesejahteraan perekonomian masyarakat Kota Mojokerto melalui kesempatan kerja. Manfaat penelitian ini adalah memberikan pertimbangan kepada masyarakat dalam menggunakan layanan transportasi online sebagai kesempatan kerja untuk mendapatkan kesejahteraan perekonomian masyarakat.

\section{METODE}

Penelitian ini merupakan penelitian dengan pendekatan kuantitatif. Penelitian kuantitatif merupakan jenis penelitian yang menggunakan angka dan bilangan terwujud (Sugiyono, 2016). Metode dalam penelitian ini menggunakan metode survey, dengan maksud menelaah, menggambarkan dan mengumpulkan serta menerangkan berbagai aspek dalam suatu fenomena yang ada di lapangan. Sedangkan populasi yang digunakan dalam penelitian ini adalah masyarakat Kota Mojokerto pada usia produktif. Sampel adalah bagian dari populasi yang akan diteliti yang dimiliki populasi. Pengambilan sampel dilakukan dengan menggunakan teknik nonprobability sampling, serta mengunakan metode pengambilan random sampling. untuk menentukan sampel pada populasi yang tidak diketahui dengan mengunakan rumus Cochran (Sugiyono, 2017). Dengan rumus sebagai berikut :

$$
n=\frac{\mathrm{Z}^{2} \mathrm{pq}}{e^{2}}
$$

Dimana :

$$
\begin{aligned}
& \mathrm{n}=\text { Jumlah sampel yang diperlukan } \\
& \mathrm{Z}=\text { Confidence level } 5 \%=1,96 \\
& \mathrm{p} \quad=\text { Peluang Benar 50\% } \\
& \mathrm{q}=\text { Peluang Salah 50\% } \\
& \text { e } \quad=\text { Kelonggaran ketidak telitian karena kesalah pengambilan sampel }
\end{aligned}
$$

Perhitungan sampel :

$$
\begin{aligned}
& n=\frac{(1,96)^{2}(0,5)(0,5)}{(0,05)^{2}} \\
& n=384,16
\end{aligned}
$$

Berdasarkan hasil perhitungan rumus di atas, maka sampel yang digunakan sebanyak 385 responden. Sedangkan pengukuran variabel dalam penelitian menggunakan skala likert. Adapun metode pengumpulan data menggunakan kuesioner yang disebarkan pada jumlah sampel yang sudah ditentukan (Sugiyono, 2017). Berikut ini kerangka pemikiran yang melandasi permasalahan tersebut akan dijelaskan sebagai 
berikut :

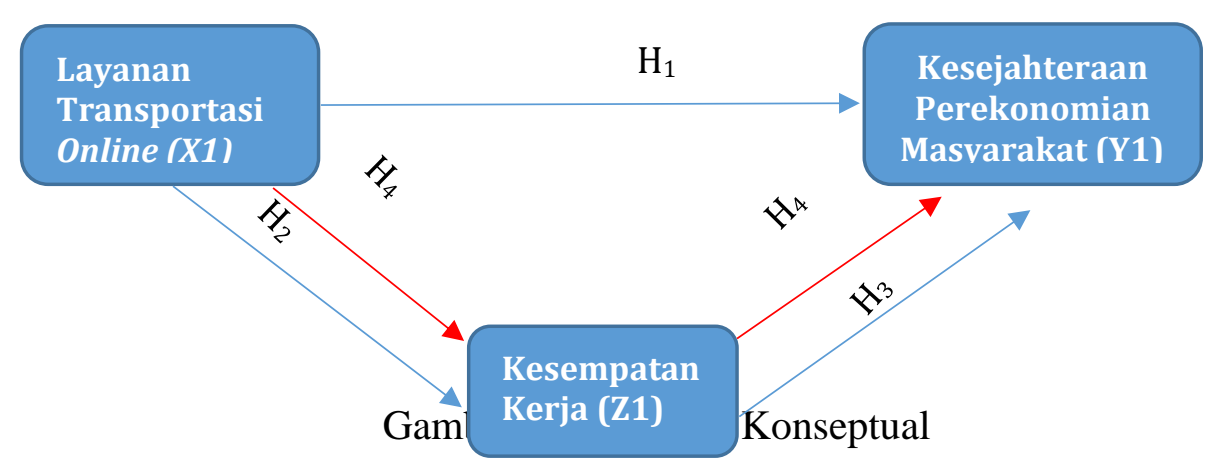

Berdasarkan latar belakang dan permasalahan, maka diajukan hipotesis sebagai berikut:

$\mathrm{H}_{1}=$ Terdapat pengaruh langsung antara Layanan Transportasi Online terhadap Kesejahteraan Perekonomian Masyarakat

$\mathrm{H}_{2}=$ Terdapat pengaruh langsung antara Layanan Transportasi Online terhadap Kesempatan Kerja

$\mathrm{H}_{3}=$ Terdapat pengaruh langsung antara Kesempatan Kerja terhadap Kesejahteraan Perekonomian Masyarakat

$\mathrm{H}_{4}=$ Terdapat pengaruh langsung antara Layanan Transportasi Online terhadap Kesejahteraan Perekonomian Masyarakat melalui Kesempatan Kerja

Metode analisis data dalam penelitian ini menggunakan PLS (Partial Least Square) dengam program smart PLS 3.0 yang merupakan metode analisis yang power full.

\section{HASIL DAN PEMBAHASAN}

\section{Hasil}

\section{a. Hasil Evaluasi Outer Model}

Pada uji convergent validity dilihat dari hasil uji outer loading yang bertujuan untuk melihat korelasi score konstruk dengan score item. Suatu indikator dinyatakan memenuhi convergent validity baik jika meiliki nilai outer loading > 0,7. Menurut Ghozali (2015) menyatakan nilai outer loading antra 0,5-0,6 bisa dinyatakan sudah dianggap cukup memenuhi convergent validity. Berikut hasil uji convergent validity dapat dilihat pada tabel 4 dibawah ini,

Tabel 4. Hasil Uji Convergent Validity

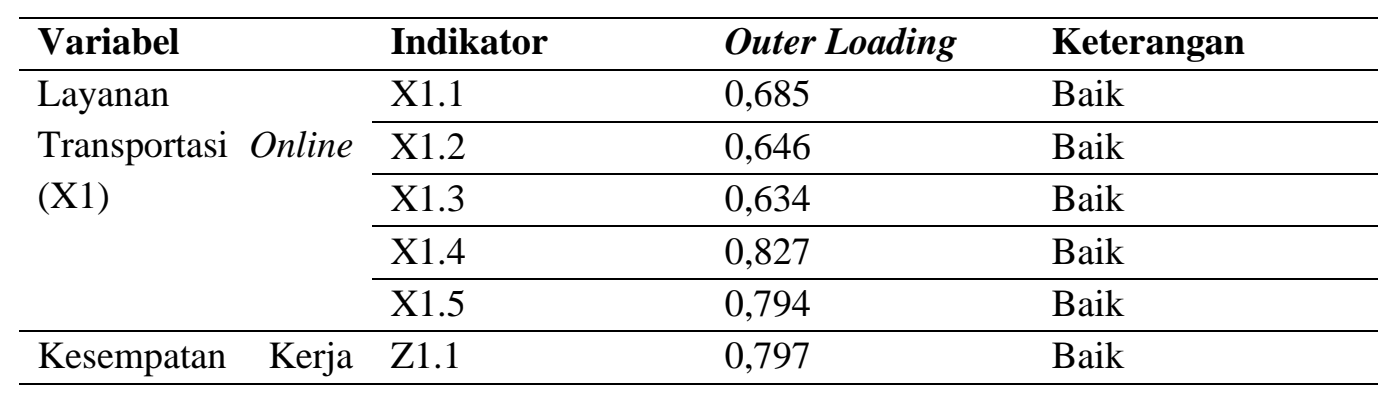




\begin{tabular}{llll}
\hline (Z1) & Z1.2 & 0,665 & Baik \\
\cline { 2 - 4 } & Z1.3 & 0,841 & Baik \\
\cline { 2 - 4 } & Z1.4 & 0,690 & Baik \\
\cline { 2 - 4 } & Z1.5 & 0,640 & Baik \\
\hline Kesejahteraan & Y1.1 & 0,669 & Baik \\
Perekonomian & Y1.2 & 0,610 & Baik \\
Masyarakat (Y1) & Y1.3 & 0,732 & Baik \\
\cline { 2 - 4 } & Y1.4 & 0,804 & Baik \\
\cline { 2 - 4 } & Y1.5 & 0,832 & Baik \\
\hline
\end{tabular}

Sumber : Data Diolah (2021)

Dari pengujian di atas diketahui bahwa indikator dari variabel layanan transportasi online, kesempatan kerja dan kesejahteraan perekonomian masyarakat memiliki nilai outer loading yang diatas 0,5 (Ghozali, 2015). Maka dapat diartikan sudah memenuhi convergent validity dan dikatakan memenuhi syarat dari kecukupan model.

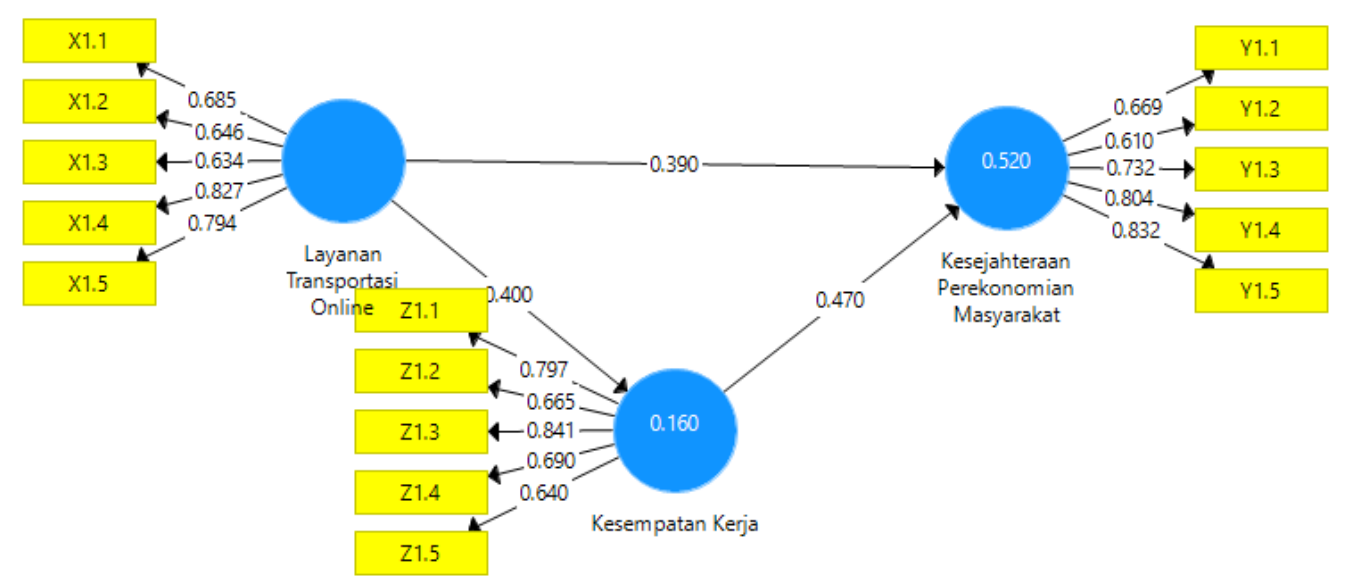

Gambar 2. Skema Model Partial Least Square (PLS)

Pada uji discriminant validity dapat dilihat dari uji average variance extracted $(A V E)$ di mana masing - masing konstruk memiliki nilai yang lebih besar dari 0,5, maka dapat dikatakan nilai discriminant validity yang valid (Ghozali, 2015). Berikut ini hasil pengolahan discriminant valid yang dapat dilihat pada tabel 5 dibawah ini;

Tabel 5. Hasil Uji Discriminant Validity dengan Average Variant Extracted (AVE)

\begin{tabular}{llc}
\hline \multicolumn{1}{c}{ Variabel } & AVE & Keterangan \\
\hline Layanan Transportasi Online (X1) & 0,539 & Valid \\
\hline Kesempatan Kerja (Z1) & 0,534 & Valid \\
\hline Kesejahteraan Perekonomian Masyarakat (Y1) & 0,520 & Valid \\
\hline
\end{tabular}

Sumber : Data diolah (2021)

Dari pengujian pada tabel di atas dapat diketahui bahwa indikator dari variabel layanan transportasi online, kesempatan kerja dan kesejahteraan perekonomian masyarakat memiliki nilai AVE diatas 0,5. Menunjukkan konstruk tersebut memiliki nilai validitas yang baik. 
Sedangkan pengujian composite reliability digunakan untuk menguji reliabilitas pada indikator - indikator variabel. Dimana dikatakan reliabel jika nilai memiliki nilai composite reliability > 0,6(Alfadri, 2019). Berikut ini hasil dari pengolahan pengujian composite reliability yang dapat dilihat pada tabel 6 dibawah ini;

Tabel 6. Hasil Uji Composite Reliability

\begin{tabular}{lcl}
\hline \multicolumn{1}{c}{ Variabel } & AVE & Keterangan \\
\hline Layanan Transportasi Online $(\mathrm{X} 1)$ & 0,852 & Reliabel \\
\hline Kesempatan Kerja (Z1) & 0,850 & Reliabel \\
\hline Kesejahteraan Perekonomian Masyarakat (Y1) & 0,843 & Reliabel \\
\hline
\end{tabular}

Sumber : Data diolah (2021)

Berdasarkan dari data hasil di atas bahwa setiap konstruk tersebut memiliki nilai composite reliability di atas 0,6 , hal itu menandakan bahwa internal consistency dari variabel layanan transportasi online, kesempatan kerja dan kesejahteraan perekonomian masyarakat memiliki nilai reliabilitas yang tinggi.

\section{b. Hasil Evaluasi Inner Model}

Signifikansi yang dijadikan parameter dan estimasi memberikan informasi yang sangat penting mengenai hubungan antar variabel. Hal ini digunakan untuk melihat hipotesis yaitu nilai yang ada pada output result for inner weight.

Pada pengujian ini dilakukan untuk menguji atau mengevaluasi path coefficient yang digunakan untuk menunjukkan hubungan yang sangat kuat pada variabel independent dari variabel dependent. Sedangkan coefficient determination ( $R$ square) digunakan untuk mengukur seberapa banyak variabel dependen dipengaruhi oleh variabel independent (Ghozali, 2015). Berikut hasil dari pengolahan path coefficient;

Tabel 7. Hasil Uji Path Coefficient

\begin{tabular}{llll}
\hline Variabel & $\begin{array}{l}\text { Layanan } \\
\text { Transportasi } \\
\text { Online }(\mathbf{X 1})\end{array}$ & $\begin{array}{l}\text { Kesempatan } \\
\text { Kerja (Z1) }\end{array}$ & $\begin{array}{l}\text { Kesejahteraan } \\
\text { Perekonomian } \\
\text { Masyarakat (Y1) }\end{array}$ \\
\hline $\begin{array}{l}\text { Layanan Transportasi } \\
\text { Online }(\mathrm{X} 1)\end{array}$ & - & 0,400 & 0,390 \\
\hline Kesempatan Kerja (Z1) & - & - & 0,470 \\
\hline $\begin{array}{l}\text { Kesejahteraan } \\
\text { Perekonomian } \\
\text { Masyarakat (Y1) }\end{array}$ & - & - \\
\hline $\begin{array}{l}\text { Sumber : Data diolah (2021) } \\
\text { Berdasarkan dari tabel di atas dapat diketahui bahwa nilai path coefficient }\end{array}$ \\
$\begin{array}{l}\text { ditunjukkan dengan adanya pengaruh layanan transportasi online (X1) terhadap } \\
\text { kesempatan kerja (Z1) sebesar 0,400, serta pengaruh layanan transportasi online }\end{array}$
\end{tabular}


(X1) terhadap kesejahteraan perekonomian masyarakat (Y1) sebasar 0,390 serta pengaruh kesempatan kerja (Z1) terhadap kesejahteraan perekonomian masyarakat (Y1) sebesar 0,470. Hal ini menunjukkan jika variabel dalam model path coefficient meiliki hubungan positif, yang artinya jika semakin besar nilainya maka semakin besar pula pengaruh antara variabel independent terhadap variabel dependent.

Berikut dapat dilihat model keseluruhan korelasi setiap variabel yang menyatakan pengaruh variabel pengaruh layanan transportasi online (X1), kesempatan kerja (Z1) dan kesejahteraan perekonomian masyarakat (Y1) yang dapat dilihat pada gambar 3 berikut ini;

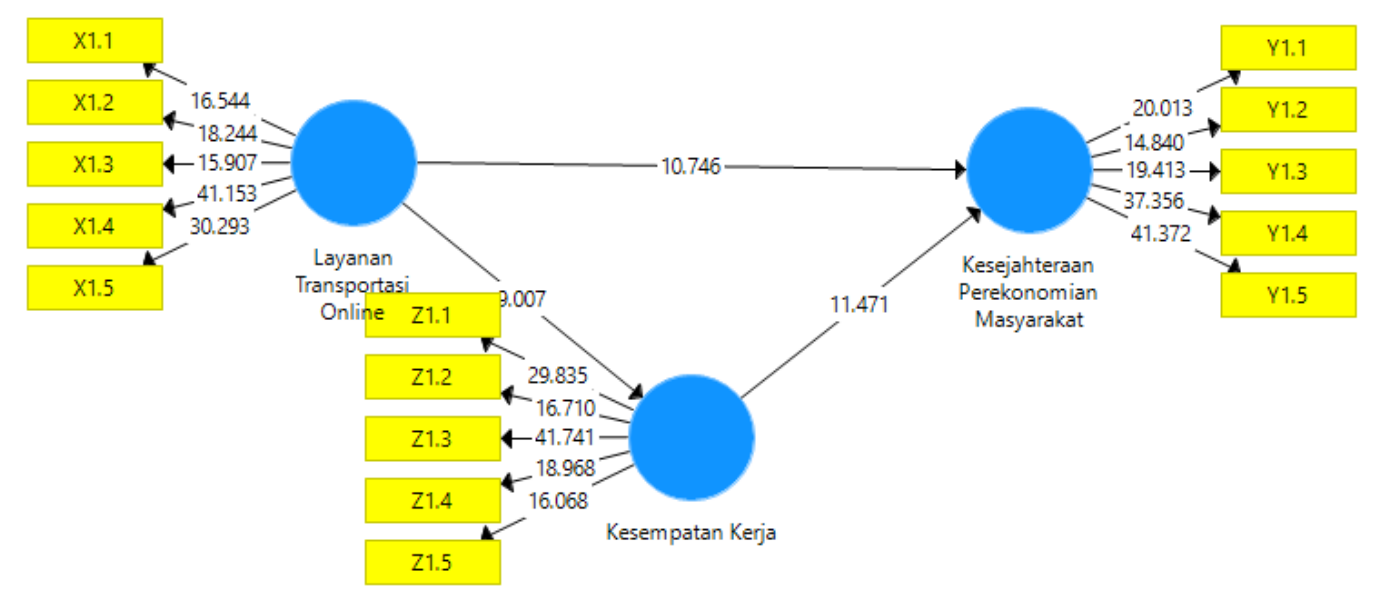

Gambar 3. Full Model Structural Partial Least Square

Output estimasi pengujian model structural dapat dilihat pada nilai t statistik dan nilai p values. Hipotesis penelitian dapat dinyatakan diterima jika memiliki nilai p value $<$ 0,005 (Yamin dan Kurniawan, 2011). Selanjutnya dalam PLS pengujian stastistik dapat digunakan untuk melihat hubungan variabel dengan melihat pengujian metode bootstrapping terhadap sampel. Pengujian dengan bootstrappping juga dimaksudkan untuk meminimalkan masalah ketidaknormalan data penelitian. Hasil pengujian dengan bootstrapping dari analisis PLS adalah dapat dilihat pada tabel 8 sebagai berikut;

Tabel 8. Hasil Uji T Statistics dan p Value

\begin{tabular}{|c|c|c|c|c|}
\hline Pengaruh Langsung & $\begin{array}{l}\text { Original } \\
\text { Sample }\end{array}$ & $\begin{array}{c}\mathbf{T} \\
\text { Statistics }\end{array}$ & $\begin{array}{c}\mathbf{P} \\
\text { Value }\end{array}$ & Hasil \\
\hline $\begin{array}{l}\text { Kesempatan Kerja -> Kesejahteraan } \\
\text { Perekonomian Masyarakat }\end{array}$ & 0,470 & 11,471 & 0,000 & Signifikan \\
\hline $\begin{array}{l}\text { Layanan Transportasi Online -> } \\
\text { Kesejahteraan Perekonomian Masyarakat }\end{array}$ & 0,390 & 10,746 & 0,000 & Signifikan \\
\hline $\begin{array}{l}\text { Layanan Transportasi Online -> } \\
\text { Kesempatan Kerja }\end{array}$ & 0,400 & 9,007 & 0,000 & Signifikan \\
\hline Pengaruh Tidak Langsung & $\begin{array}{l}\text { Original } \\
\text { Sample }\end{array}$ & $\begin{array}{c}\mathrm{T} \\
\text { Statistics }\end{array}$ & $\begin{array}{c}\mathrm{P} \\
\text { Value }\end{array}$ & Hasil \\
\hline
\end{tabular}




\begin{tabular}{lllll}
\hline Layanan Transportasi Online -> & & & & \\
Kesempatan Kerja -> Kesejahteraan & 0,188 & 7,193 & 0,000 & Signifikan \\
Perekonomian Masyarakat & & & & \\
\hline
\end{tabular}

Sumber : Data diolah (2021)

Berdasarkan hasil pengolahan data di atas, dapat diketahui bahwa hubungan antara variabel independent dengan variabel dependent memiliki hubungan yang erat dari masing -masing variabel. Variabel kesempatan kerja memiliki hubungan yang positif terhadap variabel kesejahteraan perekonomian masyarakat dilihat dari nilai T Statistics sebesar 11,471 yang lebih besar dari 1,96 dan memiliki nilai $\mathrm{P}$ Value sebesar 0,000 yang lebih kecil dari 0,05, dengan nilai original sample sebesar 0,470, variabel layanan transportasi online memiliki hubungan yang positif terhadap variabel kesejahteraan perekonomian masyarakat yang dilihat dari nilai T Statistics sebesar 10,746 yang lebih besar dari 1,96 dan memiliki nilai $\mathrm{P}$ Value sebesar 0,000 yang lebih kecil dari 0,05, dengan nilai original sample sebesar 0,390. Variabel layanan transportasi online juga memiliki hubungan yang positif terhadap variabel kesempatan kerja yang dapat dilihat dari nilai T Statistics sebesar 9,007 yang lebih besar dari 1,96 dan memiliki P Value 0,000 yang lebih kecil dari 0,05, dengan nilai original sample sebesar 0,400.

Sedangkan hubungan tidak langsung antara variabel layanan transportasi online terhadap variabel kesejahteraan perekonomian masyarakat melalui variabel kesempatan kerja juga memiliki hubungan positif dan dapat dilihat dari nilai $\mathrm{T}$ Statistics sebesar 7,193 yang lebih besar dari 1,96, serta memiliki nilai $\mathrm{P}$ value sebesar 0,000 yang lebih kecil dari 0,05, dengan nilai original sample sebesar 0,188 .

\section{Pembahasan}

1. Hubungan Langsung Layanan Transportasi Online terhadap Kesejahteraan Perekonomian Masyarakat

Secara empiris penelitian ini telah membuktikan bahwa layanan transportasi online memiliki pengaruh positif terhadap kesejahteraan masyarakat kota Mojokerto. Hal ini dibuktikan dari perolehan T stastistik sebesar 10,746 ( P value $=0,000)$ yang dapat diartikan bahwa perubahan layanan transportasi online memberikan dampak pada kesejahteraan masyarakat kota Mojokerto.

Dengan adanya perubahan dan meningkatnya pelayanan transportasi online yang ada di Kota Mojokerto membawa pengaruh pada kesejahteraan masyarakat. Hal ini dapat dilihat semakin banyaknya penyedia pelayanan trasportasi online seperi Go-jek, Grab dan juga Max On Jek yang membuka peluang bagi masyarakat 
kota untuk menjadi mitra. Dengan adanya hal ini, dapat menambah penghasilan perekonomian serta meningkatkan kesejahteraan perekonomian. Sebab para mitra tidak hanya bagi para pencari kerja tetapi banyak pelaku UMKM, pedagang kali lima yang menjadi mitra untuk mengisi waktu luang sebagai mitra (Rama, 2021). Adanya layanan transportasi online juga membantu para UMKM dalam menjalankan dan bersaing dalam bisnis khususnya makanan dan minuman, sebab dengan adanya pelayanan transportasi online UMKM dapat memasarkan produknya lebih luas lagi karena dengan adanya kerjasama antara penyedia jasa transportasi online dengan pelaku usaha makanan dan minuman, maka dapat menambah jutaan pelaku UMKM baru (Gilar Ramdhani, 2020). Penelitian ini juga senada dengan penelitian Alfadri, (2019) yang mengatakan bahwa layanan transportasi online memiliki pengaruh positif terhadap kesejahteraan perekonomian masyarakat.

2. Hubungan Langsung Layanan Transportasi Online terhadap Kesempatan Kerja

Secara empiris penelitian ini telah membuktikan bahwa layanan transportasi online memiliki pengaruh positif terhadap kesempatan kerja. Hal ini dibuktikan dari perolehan $\mathrm{T}$ stastistik sebesar 9,007 ( $\mathrm{P}$ value $=0,000$ ) yang dapat diartikan bahwa perubahan layanan transportasi online memberikan dampak pada kesempatan kerja.

Tidak dapat dipungkiri bahwa dengan adanya layanan transportasi online menambah lapangan pekerjaan baru di Kota Mojokerto. Dengan adanya layanan transportasi online, maka dapat membuka kesempatan kerja bagi warga masyarakat khususnya Kota Mojokerto baik sebagai mitra driver maupun mitra penyedia produk untuk UMKM (Sri Mas Sari - Bisnis.com, 2018). Selain itu dengan adanya layanan transportasi online ini juga menumbuhkan adanya bisnisbisnis baru terutama dalam bisnis makanan dan minuman, sebab adanya kemudahan dalam promosi maka pelaku usaha dapat mengkomunikasikan usahanya kepada masyarakat. Dengan meningkatnya usaha-usaha baru ini berdampak pada lapangan pekerjaan yang baru (Mochamad Chariris, 2020). Penelitian ini juga diperkuat dengan penelitian (Fakhriyah, 2020) yang menyatakan bahwa layanan transportasi online memiliki pengaruh langsung terhadap kesempatan kerja.

3. Hubungan Langsung Kesempatan Kerja terhadap Kesejahteraan Perekonomian Masyarakat

Secara empiris penelitian ini telah membuktikan bahwa layanan transportasi online memiliki pengaruh positif terhadap kesempatan kerja. Hal ini dibuktikan dari perolehan $\mathrm{T}$ stastistik sebesar 11,471 ( P value $=0,000$ ) yang dapat diartikan 
bahwa perubahan kesempatan kerja memberikan dampak pada kesejahteraan perekonomian masyarakat.

Upaya peningkatan kesempatan kerja tidak terlepas dari kemampuan lapangan pekerjaan dalam menyerap tenaga kerja. Dalam meningkatkan kesejahteraan perekonomian masyarakat Kota Mojokerto tentunya harus memperbanyak lapangan kerja yang ada di Kota Mojokerto. Semakin banyak lapangan kerja yang ada, maka semakin besar peluang kesempatan kerja yang akan didapat oleh masyarakat. Dilihat dari perkembangan dari tahun ke tahun diketahui jumlah pengangguran yang ada di Kota Mojokerto selalu mengalami peningkatan. Ditahun 2018 jumlah penganguran sebanyak 1.679 sedangkan pada tahun 2019 sebesar 1.715 yang mengalami peningkatan jumlah pengangguran. Bahkan pada tahun 2020 mengalami peningkatan dari tahun sebelumnya dengan 4.712 jumlah pengangguran yang ada di Kota Mojokerto akibat adanya pandemi Covid-19 (BPS Kota Mojokerto, 2021). Kenyataan ini menunjukan bahwa kesempatan kerja yang ada di Kota Mojokerto masih kurang tinggi. Itu di akibatkan jumlah lapang pekerjaan yang tersedia di Kota Mojokerto masih minim. Sedangkan semakin besar kesempatan kerja akan meningkatkan kesejahtraan perekonomian masyarakat Kota Mojokerto. Penelitian ini dikuatkan penelitian oleh Sari dan Yuedrika, (2019) yang mengatakan bahwa kesempatan kerja memiliki pengaruh langsung terhadap kesejahteraan perekonomian. Oleh karena itu pemeritah kota seharusnya membuka lapngan kerja baru dalam wilayah Kota Mojokerto sehingga kesempatan kerja untuk masyarakat semakin terbuka.

4. Hubungan Tidak Langsung Layanan Transportasi Online terhadap Kesejahteraan Perekonomian Masyarakat melalui Kesempatan Kerja

Secara empiris penelitian ini telah membuktikan bahwa layanan transportasi online memiliki pengaruh positif terhadap kesejahteraan perekonomian masyarakat melalui kesempatan kerja. Hal ini dibuktikan dari perolehan $\mathrm{T}$ stastistik sebesar 7,193 ( P value $=0,000$ ) yang dapat diartikan bahwa perubahan layanan transportasi online memberikan dampak pada kesejahteraan perekonomian masyarakat melaui kesempatan kerja.

Dari hasil penelitian di atas diketahui bahwa pertumbuhan layanan transportasi online yang baik akan meningkatkan kesempatan kerja sehingga dapat meningkatnya kesejahteraan perekonomian masyarakat Kota Mojokerto. Penelitian ini diperkuat oleh penelitian (Alfadri, 2019) yang mengatakan bahwa layanan transportasi online dapat mengurangi jumlah pengangguran serta meningkatkan kesejahteraan perekonomian masyarakat. Sehingga dapat disimpulkan jika untuk meningkatan kesejahteraan masyarakat maka kesempatan 
kerja masyarakat harus terpenuhi, serta lapangan kerja dan peluang kerja semakin terbuka luas, sehingga dapat diartikan bahwa adanya pertumbuhan layanan transportasi online berjalan sangat baik. Hal itu disebabkan dengan adanya pertumbuhan layanan online, maka semakin besar juga peluang lapangan kerja. Pertumbuhan layanan transportasi online yang ada di Kota Mojokerto bukan hanya pada perusahasan besar dan ternama saja seperti Go-Jek dan Grab, tetapi sudah bermunculan persahaan layanan transportasi yang baru seperti Max On Jek dan En-Go/ NU-Jek (Febriyanto, 2019; Mochamad Chariris, 2020). Dari peningkatan pelayanan transportasi online itu dapat membuka peluang kesempatan kerja dan peluang lapangan kerja baru di masyarakat. Hal itu dikarenakan siapapun dapat menjadi mitra, baik yang sudah bekerja dan yang belum mempunyai pekerjaan, sehingga dapat menambah penghasilan serta dapat meningkatkan kesejahteraan perekonomian masyarakat yang ada di Kota Mojokerto (Rama, 2021). Dari sini dapat disimpulkan bahwa dengan adanya pertumbuhan layanan transportasi online, maka dapat memberikan peluang kesempatan kerja dan diharapkan juga dapat meningkatkan kesejahteraan perekonomian masyarakat kota.

\section{SIMPULAN}

Berdasarkan hasil penelitian dan pembahasan, kesimpulan penelitian ini adalah ;

1. Layanan transportasi online memiliki pengaruh langsung terhadap kesempatan kerja pada masyarakat Kota Mojokerto, maka dari itu pertumbuhan layanan tranportasi online yang ada di Kota Mojokerto sangat dibutuhkan oleh masyarakat.

2. Layanan transportasi online memiliki pengaruh langsung terhadap kesejahteraan perekonomian masyarakat Kota Mojokerto, untuk meningkatkan kesejahteraan perekonomian masyarakat Kota Mojokerto sudah seharusnya menjaga pertumbuhan layanan tranportasi online dengan cara memberi ruang kepada penyedia layanan tranportasi online yang ada di Kota Mojokerto.

3. Kesempatan kerja memiliki pengaruh terhadap kesejahteraan perekonomian masyarakat Kota Mojokerto. Dengan adanya lapangan kerja yang luas maka kesempatan kerja semakin terbuka sehingga masyarakat Kota Mojokerto dapat meningkatkan kesejahteraan perekonomiannya.

4. Layanan transportasi online memiliki pengaruh terhadap kesejahteraan perekonomian masyarakat Kota Mojokerto melalui kesempatan kerja, dimana dengan adanya pertumbuhan layanan transportasi online, maka dapat memberikan peluang kesempatan kerja dan diharapkan meningkatnya pula kesejahteraan perekonomian masyarakat kota. 


\section{DAFTAR RUJUKAN}

Alfadri, F. (2019a). Pengaruh Adanya Transportasi Online terhadap Kesejahteraan Masyarakat Melalui Variabel Pengangguran di Kota Medan. Jurnal Ekonomi Dan Bisnis Islam, 3(2), 148-163. https://doi.org/10.32505/v3i2.1242

Alfadri, F. (2019b). View of Pengaruh Adanya Transportasi Online terhadap Kesejahteraan Masyarakat Melalui Variabel Pengangguran di Kota Medan. Jurnal Ekonomi Dan Bisnis Islam, 3(2), 148-163. https://doi.org/https://doi.org/10.32505/v3i2.1242

Astuti, S. A. D. (2021). Dampak Covid-19 Terhadap Ketenagakerjaan dan UMKM di Mojokerto. Jurnal Inovasi Penelitian, Februari 2021, 1(9), 1775-1778.

Awandari, L. P. P., dan Indrajaya, I. G. B. (2016). Pengaruh Infrastruktur, Investasi, dan Pertumbuhan Ekonomi Terhadap Kesejahteraan Masyarakat Melalui Kesempatan Kerja. E-Jurnal EP Unud, Desember 2016, 5(12), 1435-1462.

Aziah, A., dan Adawia, P. R. (2018). Analisis Perkembangan Industri Transportasi Online di Era Inovasi Disruptif (Studi Kasus PT. Gojek Indonesia). Jurnal Humaniora Bina Sasana Informatika, September 2018, 18(2), 149-156. https://doi.org/10.36226/jrmb.v3i2.107

BPS Kota Mojokerto. (2020). Indikator Kesejahteraan Rakyat Kota Mojokerto Tahun 2019/2020. In Katalog : 4102004.3576.

BPS Kota Mojokerto. (2021). Kota Mojokerto Dalam Angka 2021. Katalog/Catalog: 1102001.3576 .

Bustami, B., dan Laksamana, R. (2019). Transformasi Transportasi Tradisional (Offline) ke Transportasi Online Sebagai Solusi Bagi Pengguna di Kota Pontianak. Jurnal Ekonomi Bisnis Dan Kewirausahaan, 8(3), 194-203. https://doi.org/10.26418/jebik.v8i3.29404

Chandra, A. S., Yulmardi, Y., dan Erfit, E. (2020). Pengaruh pertumbuhan penduduk, inflasi, investasi, upah minimum dan kesempatan kerja terhadap pengangguran di Kota Jambi. Jurnal Paradigma Ekonomika, 15(2), 197-212. https://doi.org/10.22437/paradigma.v15i2.10321

Fahrizal, F., Zamzami, Z., dan Safri, M. (2021). Analisis pengaruh jumlah tenaga kerja, tingkat pendidikan dan investasi terhadap pertumbuhan ekonomi melalui kesempatan kerja di Provinsi Jambi. Jurnal Paradigma Ekonomika, 16(1), 167-190. https://doi.org/10.22437/jpe.v16i1.11825

Fakhriyah, P. (2020). Pengaruh Layanan Transportasi Online (Gojek) Terhadap Perluasan Lapangan Kerja Bagi Masyarakat Di Kota Cimahi. Comm-Edu (Community Education Journal), 3(1), 34. https://doi.org/10.22460/commedu.v3i1.3719 
Febriyanto. (2019). Max On Jek, Aplikasi Ojek Online Buatan Warga Mojokerto Bersaing Ketat Gojek dan Grab - Tribun Jatim. Tribunmojokerto.Com. https://jatim.tribunnews.com/2019/08/11/max-on-jek-aplikasi-ojek-onlinebuatan-warga-mojokerto-bersaing-ketat-gojek-dan-grab

Ghozali, I. (2015). Structural Equation Modeling, Metode Alternatif dengan Partial Least Square (PLS). (Edisi 4). Badan Penerbit Universitas Diponegoro: Semarang.

Gilar Ramdhani. (2020, August). Fitur Gojek Ampuh Buat Jutaan UMKM Bertahan dan Beradaptasi Selama Pandemi - Bisnis Liputan6.com. Liputan6.Com. https://www.liputan6.com/bisnis/read/4323510/fitur-gojek-ampuh-buatjutaan-umkm-bertahan-dan-beradaptasi-selama-pandemi

Gunawan, I. W., dan Arka, S. (2021). Pengaruh UMR dan Pendidikan Terhadap Kesempatan Kerja dan Pertumbuhan Ekonomi Kabupaten / Kota Provinsi BALI. E-Jurnal Ekonomi Dan Bisnis Universitas Udayana, Mei 2021, 1(5), 459-472.

Herdiansyah, D., Abdullah, A., dan Fahrizal, M. (2018). Pengembangan Model Kualitas Layanan Transportasi Online Di Indonesia. Inovbiz: Jurnal Inovasi Bisnis, 6(2), 142. https://doi.org/10.35314/inovbiz.v6i2.859

Indrayani, N. K. A., dan Setiawina, N. D. (2018). Pengaruh Partisipasi Masyarakat Dan Kebijakan Pemerintah Terhadap Kesejahteraan Masyarakat Melalui Keberlanjutan Pariwisata Nusa Penida. E-Jurnal Ekonomi Dan Bisnis Universitas Udayana, 4, 1079. https://doi.org/10.24843/eeb.2018.v07.i04.p06 Mahargiono, P. B., dan Cahyono, K. E. (2017). Kontroversi Transportasi Online Sebagai Dasar Pembenahan Fasiltas Layanan Penumpang Bagi Pelaku Bisnis Transportasi Di Surabaya. Prosiding Seminar Nasional Multi Disiplin Ilmu, 3(Sendi_U 3), 663-668.

Mochamad Chariris. (2020). Warga Ngoro Sukses Bikin Aplikasi Digital Layanan Pesan Antar. Radarmojokerto.Id. https://radarmojokerto.jawapos.com/read/2020/06/27/201248/warga-ngorosukses-bikin-aplikasi-digital-layanan-pesan-antar

PPID Kota Mojokerto. (2017). Gentur Prihantono Sandjoyo Putro Buka Job Fair 2017. Pratiwi, N. P. A., dan Indrajaya, I. G. B. (2019). Pengaruh Pertumbuhan Ekonomi Dan Pengeluaran Pemerintah Terhadap Penyerapan Tenaga Kerja Serta Kesejahteraan Masyarakat Di Provinsi Bali. Buletin Studi Ekonomi, Agustus 2019, 24(2), 220-233. https://doi.org/10.24843/bse.2019.v24.i02.p05

RadarMojokerto. (2019). Pengangguran di Kota Mojokerto Mencapai 2.340 Orang. Rama. (2021). Max On Jek, Aplikasi Ojek Online di Mojokerto - Transportasi Online 
Watch. PIJARNEWS.ID. https://www.transonlinewatch.com/max-on-jekaplikasi-ojek-online-di-mojokerto/

Rostini, Syahribulan, dan Martasia. (2020). Pengaruh Produk Domestik Bruto dan Pengeluaran Pembangunan terhadap Kesempatan Kerja di Kantor Pemerintahan Kabupaten Gowa. Sentralisasi, 9(1), 45-58.

Sari, E. P., dan Yuedrika, T. (2019). Analisis Pengaruh Transportasi Online terhadap Kesempatan Kerja dan Kesejahteraan di Kota Medan. Jurnal Ekonomi Dan Bisnis Islam, 4(2), 100-113. https://doi.org/10.32505/v4i2.1253

Sri Mas Sari - Bisnis.com. (2018, December 19). Benarkah Transportasi Online Ciptakan Lapangan Kerja? Ini Jawaban Instran - Ekonomi Bisnis.com. Bisnis.Com. https://ekonomi.bisnis.com/read/20181219/98/871365/benarkahtransportasi-online-ciptakan-lapangan-kerja-ini-jawaban-instran

Suara Surabaya.Net. (2021). Angkatan Kerja Jatim Meningkat Bersamaan Naiknya Tingkat Pengangguran Terbuka - Suara Surabaya.

Sugiyono. (2016). Metode Penelitian Kuantitatif, Kualitatif dan RdanD. PT. Alfabeta : Bandung.

Sugiyono. (2017). Metode Penelitian Kuantitatif, Kualitatif dan RdanD. Alfabeta: Bandung.

Transonline Watch.com. (2021). Max On Jek, Aplikasi Ojek Online di Mojokerto.

Yamin, S. dan H. K. (2011). Generasi Baru Mengolah Data Penelitian dengan Partial Least Square Path Modeling : Aplikasi dengan Software XLSTAT, SmartPLS, dan Visual PLS. Salemba Infotek. Jakarta. 